\title{
ANALISIS FAKTOR KEBERHASILAN PEMBERDAYAAN KADER POSYANDU SEBAGAI INTRAPRENEUR MELALUI INOVASI PRODUK BIMA-XBERBASIS CREATIVE ENTERPRENEUR
}

\author{
${ }^{1)}$ Eka Srirahayu Ariestiningsih, ${ }^{2)}$ Dwi Faqihatus Syarifah Has \\ Departement Nutrition, Faculty of Health, Muhammadiyah Gresik University \\ JI Proklamasi No 54 Gresik, 61112 East Java, Indonesia \\ 1)eka.ariesty@umg.ac.id, ${ }^{2)}$ dwi syarifah@umg.ac.id
}

\begin{abstract}
Abstrak
Posyandu merupakan salah satu unit pelayanan kesehatan yang berbasis pada masyarakat guna pengembangan sumber daya manusia secara dini dan sarat dengan upaya pemberdayaan masyarakat.Pemberdayaan kader posyandu dalam rangka peningkatan ekonomi produktif adalah semua kegiatan yang bersifat ekonomis dan produktif yang dikelola kader posyandu dalam skala mikro dan berbasis creative enterpreneur. Berdasarkan pada penelitian dan pengabdian masyarakat sebelumnya tentang efektifitas BIMA-X, maka peneliti bertujuan untuk menganalisis faktor faktor yang berpengaruh pada keberhasilan pemberdayaan kader posyandu melalui Inovasi Produk Bima-X (Biscuit PMT and Moringa Oleifera Leaf Xtract) Berbasis Creative Enterpreneur.Sample penelitian adalah Kader Posyandu Kelurahan Randuagung sebanyak 32 orang, dan sample diambil secara purposive sampling. Pengumpulan data dilakukan dengan tehnik kuesioner, wawancara dan telaah dokumen.Analisa data menggunakan uji regresi linier berganda.Hasil penelitian diketahui bahwa nilai Sig adalah sebesar 0,000. Karena nilai sig. < 0,05, maka sesuai dengan dasar pengambilan keputusan dalam uji $F$ dapat disimpulkan bahwa hipotesa diterima atau dengan kata lain Komunikasi (X1), Sumber Daya (X2), Modal/ Fasilitas (X3) dan Jejaring (X4) secara simultan terhadap Keberhasilan Pemberdayaan Kader Posyandu dan variabel independent yang berpengaruh terhadap keberhasilan Pemberdayaan Kader Posyandu adalah Sumber Daya (X2) dengan sig. < 0,05 yakni 0,000. Adanya pengaruh beberapa faktor terhadap keberhasilan pemberdayaan masyarakat diharapkan tidak hanya dilakukan di kelurahan Randuagung tapi juga dilakukan di daerah lainnya, terutama daerah dengan status ekonomi dan status gizi nya masih rendah sehingga dapat bersinergi dengan program pemerintah daerah Gresik.
\end{abstract}

Keywords: Pemberdayaan, Kader Posyandu, Inovasi produk, Intrapreneur, Creative enterpreneur

\begin{abstract}
Posyandu is one of the community-based health service units for early human resource development and laden with community empowerment efforts. The empowerment of posyandu cadres in the framework of increasing productive economy are all economic and productive activities managed by posyandu cadres on a micro scale and based on creative entrepreneurs. Based on previous research and community service on the
\end{abstract}


effectiveness of BIMA-X, the researchers aimed to analyze the factors that influence the success of posyandu cadre empowerment through Bima- $X$ Product Innovation (Biscuit PMT and Moringa Oleifera Leaf extract) Based on Creative Entrepreneurs. The sample of the research is 32 people from Posyandu Randuagung Village, and the sample is taken by purposive sampling. Data collection was carried out with questionnaire techniques, interviews and document review. Data analysis uses multiple linear regression test. The results of the study note that the Sig value is 0,000 . Because the value of sig. $<0.05$, then according to the basis of decision making in the $F$ test it can be concluded that the hypothesis is accepted or in other words Communication (X1), Resources (X2), Capital / Facilities (X3) and Network (X4) simultaneously towards the Success of Empowerment Posyandu cadres and independent variables that influence the success of Posyandu Cadres Empowerment are Resources (X2) with sig. $<0.05$ which is 0,000. The influence of several factors on the success of community empowerment is expected not only to be done in Randuagung village but also in other regions, especially areas with low economic status and nutritional status so that they can synergize with the Gresik regional government program.

Keywords: Empowerment, Cadre Posyandu, Product Innovation, Intrapreneur, Creative Entrepreneur

\section{A. Latar Belakang}

Pemberdayaan adalah segala upaya fasilitasi yang bersifat non instruktif, guna meningkatkan pengetahuan dan kemampuan masyarakat, agar mampu mengidentifikasi masalah yang dihadapi, potensi yang dimiliki, merencanakan dan melakukan pemecahannya dengan memanfaatkan potensi setempat. Adapun wahana pemberdayaan masyarakat bidang kesehatan adalah desa dan kelurahan siaga aktif yang telah ditetapkan dalam keputusan menteri kesehatan nomor 1529 tahun 2010 tentang pedoman umum pengembangan desa dan kelurahan siaga aktif(Permenkes, 2013)

Proses Pemberdayaan masyarakat dalam Pengembangan desa dan kelurahan siaga aktif dapat dilihat dari upaya masyarakat dalam melakukan siklus pemecahan masalah yang terdiri dari melakukan pengenalan kondisi desa, identifikasi permasalahan kesehatan, musyawarah desa/kelurahan, menyusun perencanaan partisipatif, pelaksanaan kegiatan hingga pembinaan kelestarian.Salah satu bentuk pemberdayaan masyarakat adalah dengan posyandu, karena pada posyandu terdapat berbagai kegiatan yang dilaksanakan dan diprakarsai oleh masyarakat sesuai dengan kebutuhan masyarakat.

Memberdayakan masyarakat berarti melakukan investasi pada masyarakat, sehingga asset dan kemampuan mereka bertambah, baik kapabilitas perorangan maupun kapasitas kelompok. Maka dari itu, untuk mendukung ide ini diperlukan adanya kerjasama antar stakeholder agar posyandu dapat semakin berkembang walaupun tampaknya sederhana, 
akan tetapi menyimpan potensi yang besar apabila dikelola secara baik (Ahap, 2015)

Posyandu yang merupakan kegiatan dari, oleh, dan untuk masyarakat sebagai salah satu bentuk unit pelayanan kesehatan yang berbasis pada masyarakat guna pengembangan sumber daya manusia secara dini.Oleh sebab itu, kegiatan Posyandu ini sarat dengan upaya pemberdayaan masyarakat.Posyandu merupakan wadah yang dapat digunakan untuk upaya pencegahan dan penanggulangan masalah kesehatan baik gizi, kesehatan ibu dan anak, Pola hidup bersih sehat, imunisasi dan sebagainya.(Nina Salamah, dkk, 2018)

Menurut Peraturan Menteri Dalam Negeri Nomor 19 tahun 2011 tentang Pedoman Pengintegrasian Layanan sosial dasar di Pos Pelayanan terpadu, Pengintegrasian layanan sosial dasar di Posyandu memperhatikan perkembangan program serta kebutuhan masyarakat. Salah satu layanan sosial dasar posyandu adalah peningkatan ekonomi keluarga, yakni dengan pembentukan simpan pinjam yang khusus dilakukan oleh kelompok perempuan, koperasi, pelatihan dan keterampilan peningkatan ekonomi keluarga (Kementerian Kesehatan Rl bekerjasama dengan Pokjanal Posyandu Pusat, 2012).

Pemberdayaan kader posyandu dalam rangka peningkatan ekonomi produktif adalah semua kegiatan yang bersifat ekonomis dan produktif yang dikelola kader posyandu dalam skala mikro dan berbasis creative enterpreneur. Pengembangan usaha ekonomi produktif kader posyandu terdiri dari: (1). Pelatihan dan Sosialisasi Kewirausahaan, (2). Pelatihan keterampilan tehnis produksi produk BIMA-X dan pengelolaan usaha, (3). Penguatan jejaring, (4) penyediaan fasilitas promosi dan pemasaran, (5). Pendampingan (Departemen Ilmu Keluarga dan Konsumen, 2013)

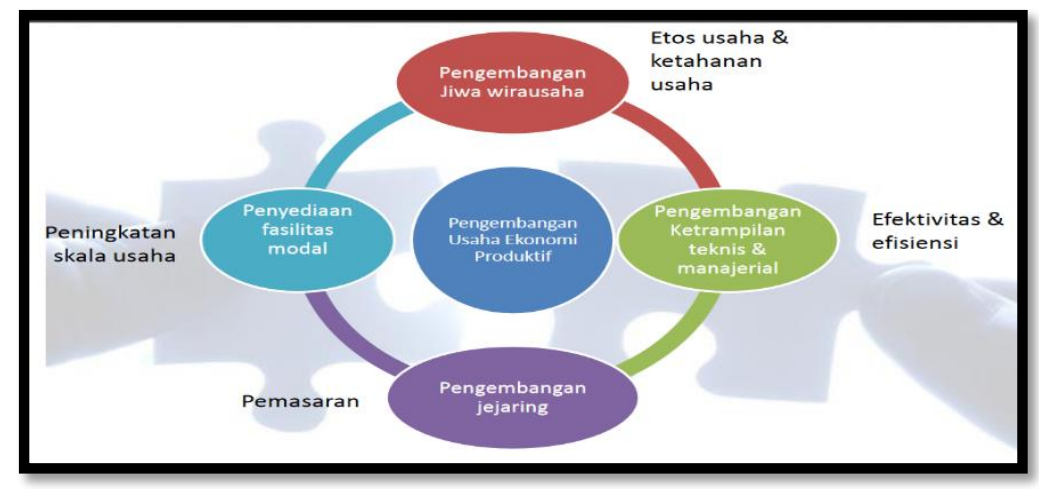

Sumber: Departemen Ilmu keluarga dan Konsumen, 2013

Gambar 1: Pengembangan Usaha Ekonomi Poduktif

Penelitian ini merupakan penelitian lanjutan dari kegiatan penelitian dan pengabdian masyarakat sebelumnya.Penelitian sebelumnya telah membahas tentang efektifitas BIMA-X terhadap peningkatan status gizi 
balita. Didapatkan bahwa efektifitas produk BIMA X sebesar 0,035 dan $p<$ 0,05 , yang artinya produk BIMA-X efektif untuk meningkatkan status gizi balita. BIMA-X adalah produk olahan dari Biskuit PMT dan ekstrak Daun Kelor (Dwi Faqihatus Syarifah, Eka Srirahayu Ariestiningsih, 2020)

Pemberian Biskuit PMT adalah salah satu bentuk suplementasi untuk meningkatkan berat badan balita, dan ekstrak Daun kelor/ 100 grmemiliki kandungan protein $28,25 \%$, vit A dalam bentuk $\beta$-Karoten $11,92 \mathrm{mg}$, kalsium $2241,19 \mathrm{mg}$, dan Magnesium sebanyak 28,03 mg. Inovasi Pengembangan Produk pangan BIMA-X diharapkan tidak hanya meningkatkan Status Gizi Balita, namun juga dapat meningkatkan status ekonomi masyarakat dalam hal ini adalah kader Posyandu (Hayati, 2014).

Pada kegiatan pengabdian masyarakat sebelumnya, Kader Posyandu dipilih sebagai pilot project untuk mengawali atau sebagai contoh dalam program inovasi produk BIMA-X sebagai produk pangan alternatif untuk pembangunan gizi berkelanjutan berbasis creative enterpreneur. Hal ini dimaksudkan karena kader posyandu dianggap sebagai komunitas yang mempunyai semangat pengabdian, berinisiatif tinggi dan mampu memotivasi masyarakat. Sehingga diharapkan kader posyandu dapat sharing of knowledge and experience kepada masyarakat tentang keberhasilan program tersebut (Dwi Faqihatus Syarifah, Eka Srirahayu Ariestiningsih, 2020)

Strategi pelaksanaan kegiatan ini terdiri dari pendekatan teknologi, bisnis, dan pendekatan kearifan lokal.Pendekatan teknologi dilakukan melalui pemanfaatan teknologi pengolahan pangan. Hal ini dilakukan dengan mengubah bentuk asli pangan lokal yang sudah ada di masyarakat dan memperkaya nilai gizi yang terkandung didalamnya melalui fortifikasi atau penambahan kandungan gizi lain secara instan. Pendekatan bisnis dilakukan dengan pola industrialisasi berbasis korporasi, peningkatan kuantitas produksi dan pemasaran. Sedangkan pendekatan kearifan lokal dilakukan dengan mempertahankan kearifan lokal terhadap budaya pola pangan setempat namun tetap memperhatikan higienitas dalam proses produksi. Selain itu, perlu dilakukan sosialisasi dan promosi kepada kader posyandu agar timbul kepercayaan diri bahwa pola konsumsi pangan lokal adalah hal sangat bijaksana untuk dipertahankan baik dari sisi kesehatan, ekomoni maupun pelestarian budaya (BKP, 2020)

Berdasarkan data dan merujuk pada penelitian dan pengabdian masyarakat diatas tentang efektifitas BIMA-X, maka peneliti bertujuan untuk menganalisis faktor faktor yang berpengaruh pada keberhasilan pemberdayaan kader posyandu melalui Inovasi Produk Bima-X (Biskuit PMT Dan Moringa Oleifera Leaf Xtract) Berbasis Creative Enterpreneur. 


\section{B. Landasan Teori \\ a. Pemberdayaan}

Pemberdayaan suatu komunitas mengacu pada proses yang memungkinkan komunitas untuk meningkatkan kontrol atas hidup mereka. "Komunitas " adalah kelompok orang yang mungkin atau mungkin tidak secara spasial terhubung, tetapi yang berbagi kepentingan umum, keprihatinan atau identitas. Komunitas ini bisa lokal, nasional atau internasional, dengan kepentingan tertentu atau luas. Pemberdayaan mengacu pada proses dimana orang mendapatkan kontrol atas faktor dan keputusan yang membentuk kehidupan mereka. Ini adalah proses di mana mereka meningkatkan aset dan atribut dan membangun kapasitas untuk mendapatkan akses, mitra, jaringan dan/atau suara, dalam rangka untuk mendapatkan kontrol kehidupan mereka.

Menurut (Laverack, 2008)menjelaskan bahwa:

"Enabling" implies that people cannot "be empowered" by others; they can only empower themselves by acquiring more of power's different forms. It assumes that people are their own assets, and the role of the external agent is to catalyse, facilitate or "accompany" the community in acquiring power.

Dari pendapat tersebut dapat disimpulkan, bahwa "Pemberdayaan menyiratkan bahwa orang tidak dapat "diberdayakan " oleh orang lain; mereka hanya dapat memberdayakan diri mereka sendiri dengan mengakuisisi lebih banyak bentuk kekuatan yang berbeda. Ini mengasumsikan bahwa orang adalah aset mereka sendiri, dan peran agen eksternal adalah untuk mengkatalarnya, memfasilitasi atau "menemani "komunitas dalam memperoleh kekuasaan.

Pemberdayaan suatu komunitas selalu membahas determinan sosial, budaya, politik dan ekonomi yang mendasari kesehatan, dan berusaha untuk membangun kemitraan dengan sektor lain dalam mencari solusi.

Komunikasi memainkan peran penting dalam memastikan pemberdayaan pada suatu komunitas.Pendekatan partisipatif dalam komunikasi yang mendorong pembahasan dan perdebatan menghasilkan peningkatan pengetahuan dan kesadaran, dan tingkat pemikiran kritis yang lebih tinggi.Berpikir kritis memungkinkan komunitas untuk memahami interaksi kekuatan yang beroperasi pada kehidupan mereka, dan membantu mereka mengambil keputusan mereka sendiri.

Pemberdayaan Kader posyandu sesuai dengan Dalam UndangUndang Nomor 17 Tahun 2007 tentang Rencana Pembangunan Jangka Panjang Nasional (RPJP-N) Tahun 2005-2025 menetapkan bahwa Pembangunan Kesehatan diarahkan untuk meningkatkan kesadaran, kemauan dan kemampuan hidup sehat bagi setiap orang agar peningkatan 
derajat kesehatan masyarakat setinggi-tingginya dapat terwujud. Selanjutnya, dalam Rencana Strategis Kementerian Kesehatan Tahun 2010-2014 yang tertuang dalam Keputusan Menteri Kesehatan Republik Indonesia Nomor: HK.03.01/160/1/2010 telah ditetapkan bahwa visi Kementerian Kesehatan adalah "masyarakat sehat yang mandiri dan berkeadilan". Masyarakat sehat yang mandiri adalah suatu kondisi dimana masyarakat Indonesia menyadari, mau dan mampu mengenali, mencegah dan mengatasi permasalahan kesehatan yang dihadapi sehingga dapat bebas dari gangguan kesehatan, baik yang disebabkan karena penyakit termasuk gangguan kesehatan akibat bencana, maupun lingkungan dan perilaku yang tidak mendukung untuk hidup sehat, dengan menggunakan potensi yang dimilikinya.

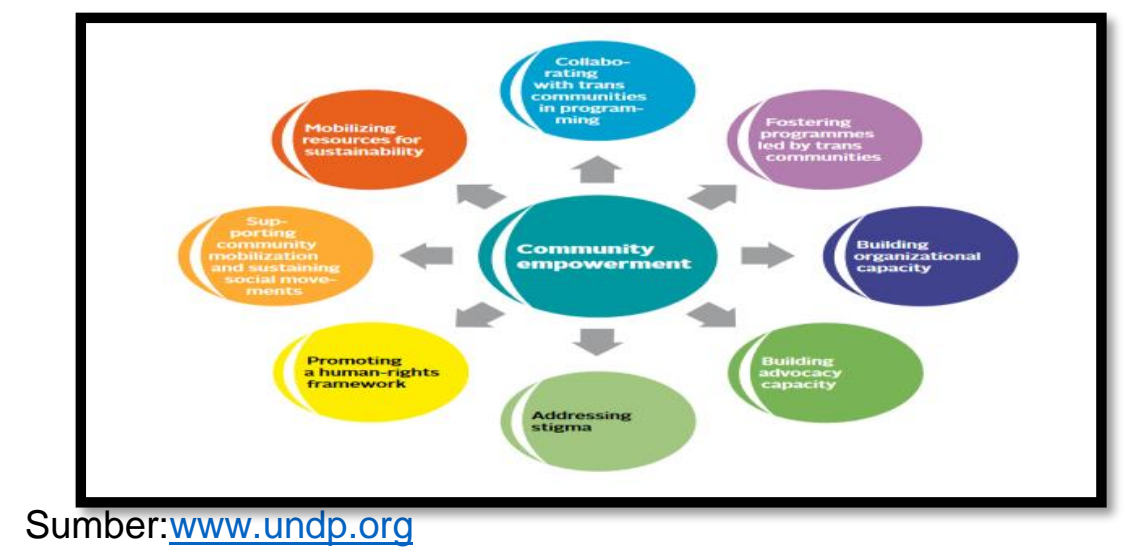

Gambar 2: Key Elements of Community Empowerment among Trans People

Pada gambar diatas dapat disimpulkan bahwa ada 7 element yang menjadi kunci dalam keberhasilan suatu pemberdayaan di komunitas dalam hal ini adalah komunitas ibu ibu kader posyandu. 7 elemen tersebut adalah: (1) Membangun kapasitas organisasi (2) Membangun kapasitas kebijakan (3) pandangan yang dituju (4) Mempromosikan kerangka kerja has asasi manusia (5) Mendukung pergerakan komunitas dan keberlanjutannya (6) Pergerakan sumber daya untuk keberlanjutan (7) Kolaborasi program dengan trans-community.

\section{b. Kader Posyandu}

Posyandu merupakan salah satu bentuk Upaya Kesehatan Bersumber Daya Masyarakat (UKBM) yang dikelola dan diselenggarakan dari, oleh, untuk, dan bersama masyarakat dalam penyelenggaraan pembangunan kesehatan, guna memberdayakan masyarakat dan memberikan kemudahan kepada masyarakat dalam memperoleh pelayanan kesehatan dasar, utamanya untuk mempercepat penurunan angka kematian ibu dan bayi. Upaya pengembangan kualitas sumber daya manusia dengan mengoptimalkan potensi tumbuh kembang anak dapat dilaksanakan secara 
merata, apabila sistem pelayanan kesehatan yang berbasis masyarakat seperti Posyandu dapat dilakukan secara efektif dan efisien serta menjangkau semua sasaran yang membutuhkan layanan bayi dan balita, ibu hamil, ibu menyusui, ibu nifas, PUS, dan WUS.

Pengintegrasian layanan sosial dasar di Posyandu merupakan upaya mensinergikan berbagai layanan yang dibutuhkan masyarakat meliputi perbaikan kesehatan dan gizi, pendidikan dan perkembangan anak, peningkatan ekonomi keluarga, ketahanan pangan keluarga dan kesejahteraan sosial.Oleh sebab itu, penyelenggaraannya mendapatkan bimbingan dari petugas Puskesmas, lintas sektor, dan lembaga terkait lainnya (Kementerian Kesehatan RI bekerjasama dengan Pokjanal Posyandu Pusat, 2012).

Revitalisasi Posyandu sejalan dengan Keputusan Menteri Kesehatan Nomor 1529 Tahun 2010 tentang Pedoman Umum Pengembangan Desa dan Kelurahan Siaga Aktif bahwa keaktifan Posyandu merupakan salah satu kriteria untuk mencapai Desa dan Kelurahan Siaga Aktif. Untuk memantapkan upaya dimaksud dan dalam rangka pengintegrasian layanan sosial dasar di Posyandu yang memerlukan peran serta pemerintah daerah dan lintas sektor maka ditetapkan Peraturan menteri dalam negeri nomor 19 tahun 2011 tentang Pedoman Pengintegrasian Layanan sosial dasar di Pos Pelayanan terpadu. Pengintegrasian layanan sosial dasar di Posyandu dan memperhatikan perkembangan program serta kebutuhan masyarakat sebagaimana dimaksud meliputi:

1. Pembinaan gizi dan kesehatan ibu dan anak.

2. Pengendalian penyakit dan penyehatan lingkungan.

3. Perilaku hidup bersih dan sehat.

4. Kesehatan lanjut usia.

5. BKB.

6. Pos PAUD.

7. Percepatan penganekaragaman konsumsi pangan.

8. Pemberdayaan fakir miskin, komunitas adat terpencil, dan

9. Penyandang masalah kesejahteraan sosial. Kesehatan reproduksi remaja.

10. Peningkatan ekonomi keluarga.

Peningkatan ekonomi keluarga dalam pengintegrasian layanan posyandu dapat dilakukan dengan cara berwirausaha. Berwirausaha dilakukan oleh seorang wirausahawan yang mempunyai tenaga, keinginan untuk terlibat dalam peualangan inovatif, kemauan untuk menerima tanggung jawab pribadi dalam mewujudkan suatu peristiwa dengan cara yang mereka pilih, dan keinginan untuk berprestasi yang sangat tinggi.

Peningkatan ekonomi keluarga dalam posyandu salah satunya adalah dengan menambah keterampilan membuat atau memproduksi produk 
makanan.Kader Posyandu sebagai pilot project atau contoh masyarakat melakukan wirausaha produk yang bernilai gizi tinggi dan berasal dari bahan pangan potensi lokal.

\section{c. Inovasi}

Innovation is the ability to apply creative solution to those problem and opportunities to enchance or to enrich people's live. (Keinovasian adalah kemempuan menerapkan pemecahan-pemecahan persoalan secara kreatif dan menciptakan peluang untuk meningkatkan atau memperkaya kehidupan manusia) (zimmerer, 1996 51) seperti dikutip Suryani.Inovasi merupakan tindakan kewirausahaan untuk meraih sukses dalam persaingan (Suryana 2014:74).Suryana (2013: 32-34) mengemukan bahwa secara multidimesional, inovasi memiliki beberapa makna penting yang mencakup hal-hal sebagaiberikut:

a. Innovation as novelty

Pada hakikatnya inovasi adalah pembaruan atau kebaruan yang menghasilkan nilai tambah baru bagi penggunanya. Obyek inovasi adlah nilai tambah suatu produk, atau proses atau jasa.

b. Innovation as change

Inovasi merupakan perubahan, perubahan bisa dalam bentuk transformasi difusi yang berujung pada perubahan. Inovasi diawali dengan proses baru untuk menghasilkan obyek baru.

c. Innovation as Advantage

Inovasi adalah keunggulan, dengan inovasi berarti kita menciptakan keunggulan-keunggulan dalam bentuk yang baru.Inovasi bisa dalam berbagai bentuk sperti inovasi produk,proses, metode, teknologi dan manajemen.

\section{Cara berinovasi}

Menurut Kotler dan Keller (2006) sperti dikutip Suryana (2014:75) ada empat jenis cara berinovasi yang dapat dilakukan:

a. Dengan cara penemuan, yaitu dengan mengkreasi suatu produk, jasa atau proses yang belum pernah dilakukan sebelumnya

b. Dengan cara pengembangan, yaitu dengan cara mengembangkan produk, jasa atau proses yang ada

c. Dengan cara duplikasi, yaitu dengan cara peeniruan produk, jasa atau proses yang sudah ada. Duplikasi ini bukan semata-mata meniru melainkan menambah seutuhnya secara kreatif agar mampu memenangkan persaingan

d. Dengan cara sintetis, yaitu dengan cara perpaduan konsep dan faktorfaktor yang sudah ada menjadi formulasi baru 


\section{d. Produk BIMA-X}

Bima-X (Biskuit PMT dan Moringa Oleifera Leaf Ekstrak) adalah produk makanan yang berasal dari Biskuit PMT dan ekstrak Daun Kelor.Pemilihan produk angan dari PMT karena Biskuit PMT didistribusikan oleh pemerintah, dibagikan untuk ibu hamil dan anak balita terutama dengan status gizi kurus (wasting) untuk pemulihan.Tiap 100 gr PMT biskuit mengandung makro dan mikronutrien yang sudah didesain untuk mencukupi kebutuhan gizi anak balita. Awalnya, biskuit didisain untuk mencukupi kebutuhan energi kandungan kalori dan mikronutriennya cukup tinggi yaitu540 kalori, 14 gr lemak, 9 gr protein, dan 71 gr karbohidrat. Usia 6-11 bulan diberikan 8 keping per hari selama 1 bulan, setara dengan 20 bungkus PMT Balita. Usia 12-59 bulan diberikan 12 keping per hari selama 1 bulan, setara dengan 30 bungkus PMT Balita.

Efektivitas program untuk PMT pada baduta, karena pada usia ini anak masih dalam fase pembelajaran dalam mengenal makanan lunak dan padat. Pada usia 6-23 tahun, anak baduta telah lepas dari fase ASI eksklusif dan sedini mungkin diperkenalkan dengan makanan cair dan lunak untuk kemudian pada usia 1 tahun sudah diperkenalkan dengan makanan padat seperti yang disajikan dalam makanan keluarga. Dalam fase mengenali makanan tersebut, kemampuan anak baduta untuk menerima program PMT yang diberikan masih menjadi suatu permasalahan. Anak-anak kita sering menolak dengan berbagai alasan, tidak suka, rasa yang terlalu manis, bosan dan lain lain sehingga pada tiap bulannya pembagian biskuit PMT pada anak anak Baduta dirasa kurang efektif dan efisien oleh kader posyandu dan masyarakat (Rifqi, 3 March 2019).

Daun Kelor (Moringa Oleifera Leaf) Berdasarkan informasi yang didapatkan dari DKBM Indonesia 2019, daun kelor mengandung zat gizi makro dan zat gizi mikro.Daun Kelor (Moringa Oleifera) dikenal di seluruh dunia sebagai tanaman bergizi dan WHO telah memperkenalkan kelor sebagai salah satu pangan alternatif untuk mengatasi masalah gizi (malnutrisi).Di Afrika dan Asia daun kelor direkomendasikan sebagai suplemen yang kaya zat gizi untuk ibu menyusui dan anak pada masa pertumbuhan.Semua bagian dari tanaman kelor memiliki nilai gizi, berkhasiat untuk kesehatan dan manfaat dibidang industri. Selain dikonsumsi langsung dalam bentuk segar, kelor juga dapat diolah menjadi bentuk tepung atau powder yang dapat digunakan sebgai bahan fortifikan pada berbagai produk pangan, seperti pada olahan pudding, cake, nugget, biscuit, cracker serta olahan lainnya. Menurut Prajapati et al (2003) tepung daun kelor dapat ditambahkan untuk setiap jenis makanan sebagai suplemen gizi (Winarno, 2018). 
Ekstrak Daun Kelor, dibuat dengan cara menghaluskan daun kelor. Daun kelor yang sudah halus kemudian dicampur dengan Biskuit PMT yang sudah dihancurkan.Biskuit PMT dibuat sebagai subtitusi dari tepung terigu. BIMA-X dibuat dalam beberapa varians sajian, yakni: ice cream BIMA-X, Siomay BIMA-X, Nugget BIMA-X dan Crackers BIMA-X. Tujuan dari pembuatan beberapa varians rasa BIMA-Xadalah agar balita tidak bosan dengan varians yang ada, sehingga pemberian BIMA-X dapat efektif dan efisien.

\section{e. Creative Enterpreneur}

\section{Pengertian Creative Enterpreneur} Creative (Kreativitas)

Kreativitas, adalah berpikirsesuatu yang baru dan berbeda (thinking new things), sedangkan inovasi adalah melakukan sesuatu yang baru dan berbeda. Menurut Drucker, 1994 yang dikutip suryana hakikat kewirausahaan adalah kemampuan berpikir sesuatu yang baru dan berbeda (thinking new things and different).

Menurut Sternberg (1997), kreativitas adalah kinerja manusia sangat komplek yang meliputi semua bentuk karya manusia baik yang berwujud (produk) maupun tidak berwujud termasuk desain, proses dan ide. Proses kreativitas tidak terjadi secara kebetulan melainkan sebuah upaya yang sengaja dilakukan.

Kreativitas adalah kemampuan untuk berpikir yang baru dan berbeda, sedangkan inovasi adalaah kemampuan untuk bertindak yang baru dan berbeda.Nilai inovatif, kreatif, dan fleksibilitas merupakan unsur-unsur keorisinalitasan seseorang. Wirausahawan Inovatif (Innovation Entrepreneur) adalah orang kreatif dan yakin dengan adanya cara-cara baru yang lebih baik (yuyun Wirasasmita, 1994 :7) dalam Suryana, 2014. Dari semua definisi tersebut, jelas bahwa mereka berbagi pandangan bahwa kreativitas adalah sesuatu: baru, inovatif, asli dan unik.

\section{Komponen Kreativitas.}

Ada enam persyaratan sebagai modal dasar agar seseorang atau organisasi bisa disebut kreatif (Sternberg, 1997) dikutip Adriana Bujor dan Silvia Avasilcai (Procedia 21-28).

a. Pengetahuan: mengetahui apa yang dianggap baru bukan sekedar menemukan kembali apa yang sudah ada.

b. Kemampuan intelektualitas: kemampuan untuk menghasilkan ide, mengevaluasinya dan menerapkan ide tersebut. 
c. Cara berpikir kreatif: seseorang memiliki preferensi untuk berpikir dengan cara baru bukan sekedar cara berpikir konvensional.

d. Motivasi: ada keinginan dan upaya yang konsisten untuk terus bergerak dan menemukan sesuatu yang baru dan menjadikan segala sesuatunya terasa menyenangkan

e. Kepribadian: dalam diri seseorang terdapat sifat yang persisten dan bulat untuk mengatasi berbagai macam hambatan.

f. Lingkungan: ada dukungan sehingga seseorang berani mengambil resiko misalnya resiko untuk melakukan kegiatan yang tidak populer.

\section{Karakteristik Kreativitas}

Karaterikstis kreativitas menurut Swann dan Birke (2005) yang dikutip Brian Barnard, Derrick Herbst (2018) menyatakan bahwa ada tiga aspek kritis yaitu: bisociation, otonomi, dan inkubasi.

a. Bisociation adalah kegiatan kombinatorial: menyatukan berbagai perspektif yang berbeda tentang masalah yang sama. Perbedaan dibuat antara keterampilan berpikir rutin pada satu bidang, dan tindakan kreatif yang selalu beroperasi pada lebih dari satu bidang;

b. Otonomi menyangkut fakta bahwa orang kreatif perlu membangun kemandirian intelektual dan kreatifnya sendiri;

c. Inkubasi berkaitan dengan kenyataan bahwa kreativitas biasanya tidak mengambil bentuk kilasan inspirasi yang tiba-tiba. Sebaliknya, kreativitas adalah puncak dari pemikiran dan upaya yang berkelanjutan - atau inkubasi. Ini bukan untuk menyangkal bahwa terobosan terakhir mungkin muncul secara tiba-tiba, tetapi untuk menekankan bahwa terobosan tersebut dibangun di atas pemikiran panjang yang melelahkan.

\section{Entrepreneur (Wirausahawan)}

An entrepreneur is one who creates e new business on the face risk and uncertainty for the purpose of achieving profit and growth by identifying opportunities snd assembing the necessary resources to capitalize on those opportunities(Norman M. Scarborough dan Thomas W Zimmerer (1993) dalam Suryana 2024

(Wirausahawan adalah seseorang yang menciptakan suatu bisnis baru dalam menghadapi risiko dan ketidakpastian untuk maksud memperoleh keuntungan dan pertumbuhan dengan cara mengidentifikasi peluang dan mengombinasikan sumber-sumber daya yang diperlukan untuk memanfaatkan peluang tersebut). 
Entrepreneur adalah seorang yang mengorganaisasikan dan mengarahkan usaha baru, wirausahawan berani mengambil risiko yang terkait dengan proses pemulaian usaha (David E. Rye (1996)

\section{Jenis-jenis Entrepreneur (Wirausahawan)}

Roopke (1995:5) seperti dikutip Suryana 2014 mengelompokkan kewirausahaan berdasarkan pada perannya sebagai berikut:

a. Wirausahawan rutin: yaitu wirausahawan (Entrepreneur) yang melakukan kegiatan sehari-harinya cenderung berfokus pada pemecahan masalah dan perbaikkan standar prestasi tradisional

b. Wirausahawan arbitrase: yaitu wirausahawan (Entrepreneur) yang selalu mencari peluang melalui kegiatan penemuan (pengetahuan) pemanfaatan

c. Wirausahawan Inovatif: yaitu wirausahawan (Entrepreneur) dinamis yang menghasilkan ide dan kreasi baru yang berbeda.

Mufti Maubarok berpendapat bahwa sejalan dengan semakin pesatnya perkembangan ilmu pengetahuan dan teknologi muncul beberapa jenis atau tipe wirausahawan seperti dikutip Eka Ariestiningsih

a. Wirausahawan Bisnis (Business Entreprenur)adalah wirausahawan yang bergerak dibidang produksi barang atau jasa dan pemasarannya

b. Technopreneur: seorang wirausahawan yang menghasilkan kekayaan dengan cara memanfaatkan teknologi informasi yang berkembang pesat

c. Wirausahawan Sosial (Social Entrepreneur) adalah wirausahawan yang bergerak dibidang usaha perbaikkan kondisi-kondisi sosial, lingkungan dan ekonomi

d. Wirausahawan Kreatif (Creative Entrepreneur) adalah orang-orang yang menggunakan kreatifitas untuk memunculkan kekayaan dalam dirinya sendiri dari pada menggunakan modal eksternal

Kesimpulan dari pendapat diatas, pada dasarnya inovation entrepreneur adalahsama dengan creative entrepreneur.

Selanjutnya menurut Zimmmerer mengemukakan pengelompokkan wirausahawan berdasarkan profilnya adalah sebagai berikut:

a. Part time entrepreneur, yaitu wirausahawan yang hanya setengah waktu melakukan usaha, biasanya sebagai hobi. Kegiatan usahanya hanya bersifat sampingan

b. Home based new venrures, yaitu usaha yang dirintisd dari rumah ( tempat tinggal)

c. Family owned business, yaitu usaha yang dilakukan/ dimiliki beberapa anggota keluarga secara turun-menurun. 
d. Copreneurs, yaitu usaha yang dilakukan oleh dua orang wirausahawan yang bekerja sama sebagai pemilik dan menjalankan usahanya bersama-sama.

Istilah entrepreneur sesuai dengan bidangnya (Suryana 2014: 59)

a. Intrapreneur

Yaitu orang yang tidak menemukann sessuatu (produk) yang beru, tetapi menggunakan temuan orang lain yang dipakai pada unit usahanya yang bersangkutan.

b. Edupreneur

Yaitu istilah yang digunakan oleh para pendidik dalam mengembangkan bidang pendidikan secara kreatif dan inovatif untuk mengembangkan kemampuan mendidik dan anak didiknya

\section{Creative Entrepreneur}

Menurut John Howkins Creative Entrepreneur, adalah orang-orang yang menggunakan kreativitas untuk memunculkan kekayaan didalam diri mereka sendiri ketimbang menggunakan modal eksternal. Creative Entrepreneuradalah orang yang bergerak dibidang usaha, dalam semua bidang usaha yang menjadi modal utamanya adalah kreativitas dalam menciptakan suatu produk. Setiap produk yang dihasilkan creative entrepreneur merupakan produk yang unik. (Mufty Mubarok, 2013)

Menurut Triawan Munaf, creative preneur sebagai orang yang terlibat dalam ekonomi kreatif dengan gagasan apapun yang punya nilai dan bisa mensejahterakan baik yang menciptakan maupun yang menggunakan (kompasiana: kalliysa Deviana Putri, 17 Januari, 10.30) Menurut Wikipedia, dikutip (Adriana Bujor dan Silvia Avasilcai) kewirausahaan kreatif adalah praktek mendirikan bisnis atau wirausaha di salah satu industri kreatif (Wikipedia, 2013). industri kreatif kewirausahaan merupakan cara berpikir baru, sikap baru, yaitu untuk mencari peluang dalam organisasi budaya, dalam hal misi kebudayaan mereka sebagai titik awal, bisnis kreatif yang lebih aktif daripada jenis lain dari bisnis dalam mempromosikan inovasi. Tantangan yang sebenarnya bahwa mereka yang berani untuk terlibat dalam kewirausahaan harus mengemukakan kreatif, yang menrupakan kebutuhan untuk menemukan keseimbangan antara sisi artistik, dan pembiayaan dan sisi pengembangan bisnis.

Dari istilah kewirausahaan dalam industri kreatif (kreatif / kewirausahaan budaya) berasal istilah pengusaha di industri kreatif (entrepreneur kreatif), yang berkaitan dengan realisasi strategi, desain organisasi dan kepemimpinan dalam konteks budaya.Gagasan ini mencirikan mereka 
pengusaha berbakat dan sukses, mampu mengubah ide-ide mereka menjadi produk atau jasa yang dibutuhkan masyarakat.

Menurut Throsby, 2011 seperti dikutip Saskia De Klerk, menyebutkan bahwa creative entrepreneur adalah eksekutif bisnis yang beroperasi di sektor ekonomi industri kreatif, memiliki karakteristik khas yang memengaruhi orang-orang di sekitar mereka karena sifat industri kreatif, posisi mereka dalam masyarakat, dan hubungan mereka dengan orangorang dalam operasi bisnis mereka. Orang-orang ini bekerja bersama menuju kesuksesan dalam ekosistem inovasi. Berbagai macam keinovasian ada dalam hal kerja sama, kompetensi, kompetisi dan peluang penciptaan bersama dalam lingkungan yang fleksibel dan tidak pasti

Roopke (1995) berpendapat Inovation Entrepreneur: yaitu wirausahawan (Entrepreneur) dinamis yang menghasilkan ide dan kreasi baru yang berbeda. Hal tersebut merupakan penggerak/ penggagas, tidak saja memperkenalkan teknik dan produk baru, tetapi juga dalam pemasaran dan sumber pengadaan, peningkatan teknik manajemen dan metode distribusi baru

Kesimpulan dari pendapat tersebut adalah creative entepreneur/ inovation entrepreneur adalah seseorang yang menuangkan bakat kreativitasnya menjadi bisnis.

\section{Komponen dalam Creative Entrepreneur/Inovation Entrepreur}

Unsur-unsur/ komponen-komponen yang terdapat pada creative entrepreur/ innovation entrepreur adalah : (1) Ide kreatif dan inovasi; (2) Modal internal; (3) menyejahterakan pencipta dan pengguna; (4) Mencari peluang mendirikan bisnis; (5) memanage (mengelola secara profesional); (6) model pemasaran baru; (7) sumber pengadaan, (8) peningkatan teknik manajemen; (9) metode distribusi baru.

\section{Pola kegiatan Creative Entrepreneur/Inovation Entrepreur}

Gambaran proses Creative Entrepreneur atau Innovation Entrepreneur adalah sebagai berikut: 


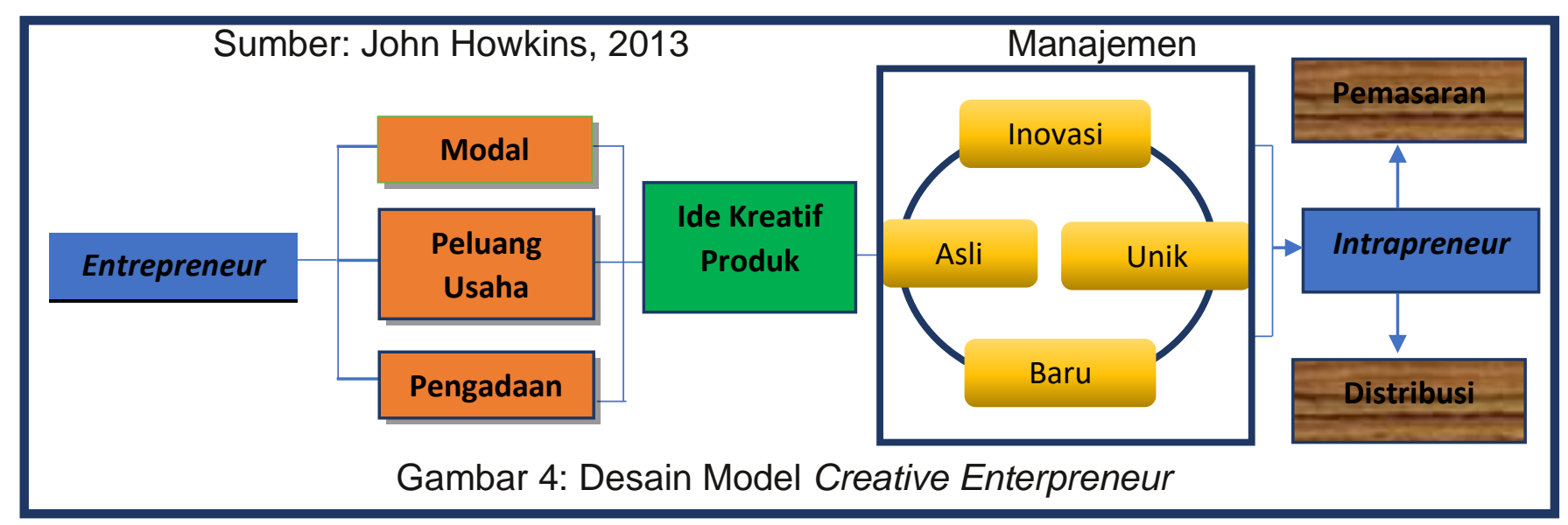

\section{Metode Penelitian}

Desain Penelitian ini adalah merupakan penelitian korelasional, yang bertujuan untuk mengkaji faktor yang mempengaruhi keberhasilan program pemberdayaan Kader Posyandu sebagai intrapreneur melui inovasi produk BIMA-X berbasis Craetive Enterpreneur. Variabel penelitian ini adalah Komunikasi (X1), Sumber Daya (X2), Penyediaan Modal dan Fasilitas (X3), serta Jejaring (X4) sebagai variabel independen, serta keberhasilan pemberdayaan kader posyandu adalah variabel dependent.

Indikator variabel Informasi adalah: transmisi, kejelasan dan konsistensi informasi dalam penyuluhan / pendampingan. Variabel Sumber Daya indikator nya adalah penguasaan teknik/cara, Skill keterampilan, Kemampuan manajerial dan kualitas layanan pendampingan.Variabel Penyediaan Fasilitas dan Modal indikatornya adalah ketersediaan sarana dan prasarana pendukung kegiatan, ketersediaan modal baik dari desa mapupun swadaya masyarakat. Variabel Jejaring/ Mitra kerjasama indikatornya adalah adanya mitra kerjasama dan pengembangan usaha secara online.Selanjutnya indokator dari keberhasilan pemberdayaan kader posyandu adalah terdapatnya kemajuan usaha, kelangsungan usaha dan kemandirian para masing masing kader posyandu.

Sumber data adalah ahli gizi dan bidan koordinator Puskesmas Kebomas yang menjadi pengawas kegiatan posyandu.Kader Posyandu sebanyak 32 orang, dan sample diambil secara purposive sampling.Pengumpulan data dilakukan dengan tehnik kuesioner, wawancara dan telaah dokumen.

Kuesioner disusun menggunakan skala Likert dengan lima alternatif jawaban. Telaah dokumen yaitu digunakan untuk mencari keterangan atau pengumpulan data sekunder yang berkaitan dengan pokok permasalahan mengenai pemberdayaan Kader Posyandu.Sedangkan untuk teknik wawancara digunakan untuk mengumpulkan data terkait 
pelaksanaan program pemberdayaan kader posyandu dengan sumber data dari para pelaksana program pemberdayaan kader posyandu yakni Bidan Koordinator dan Ahli GiziPuskesmas Kebomas. Data dianalisis dengan teknik analisis statistik deskriptif dengan menggunakan persentase, sedangkan pengujian hipotesis penelitian menggunakan uji regresi linier berganda dengan program SPSS.

Lokasi penelitian ini bertempat di Kelurahan Rauduagung, Kecamatan Kebomas, Kabupaten Gresik.

\section{Hasil Penelitian}

Faktor yang diteliti dalam penelitian ini adalah tingkat keberhasilan program pemberdayaan Kader Posyandu sebagai intrapreneur melalui produk inovasi BIMA-X berbasis Creative Enterpreneur yang terdiri dari Komunikasi, Sumber Daya, Modal dan Fasilitas, serta Jejaring / Kerjasama Mitra.Berdasarkan tabel output SPSS, diketahui bahwa nilai Sig adalah sebesar 0,000. Karena nilai sig. $<0,05$, maka sesuai dengan dasar pengambilan keputisan dalam uji $\mathrm{F}$ dapat disimpulkan bahwa hipotesa diterima atau dengan kata lain Komunikasi (X1), Sumber Daya (X2), Modal/ Fasilitas (X3) dan Jejaring (X4) secara simultan terhadap Keberhasilan Pemberdayaan Kader Posyandu.

Berdasarkan tabel output SPSS diatas, diketahui nilai Fhitung adalah sebesar 22,771. Karena F Hitung 22,771 > F Tabel, maka sebagaimana dasar pengambilan keputusan dalam uji $\mathrm{F}$ dapat disimpulkan bahwa hipotesis diterima atau dengan kata lain Komunikasi (X1), Sumber Daya (X2), Modal/ Fasilitas (X3) dan Jejaring (X4) secara simultan berpengaruh terhadap Keberhasilan Pemberdayaan Kader Posyandu. Berikut ini adalah tabel ringkasan hasil analisis regresi berganda.

Tabel 1: Hasil Analisis Regresi Berganda

\begin{tabular}{|l|c|c|c|}
\hline \multicolumn{1}{|c|}{ Variabel } & $\begin{array}{c}\text { Koefisien } \\
\text { Regresi }\end{array}$ & thitung & Sig \\
\hline Konstanta & 0,141 & 1,641 & 0,112 \\
\hline Komunikasi (X1) & $-0,061$ & $-0,245$ & 0,809 \\
\hline Sumber Daya (X2) & 0,974 & 4,285 & 0,000 \\
\hline Modal dan Fasilitas (X3) & 0,121 & 0,776 & 0,444 \\
\hline Jejaring (X4) & $-0,164$ & -1.093 & 0,284 \\
\hline F Hitung: 22,71 & & & 0,000 \\
\hline R Square:0,771 & & & \\
\hline
\end{tabular}

Berdasarkan tabel diatas diketahui bahwa variabel independent yang berpengaruh terhadap keberhasilan Pemberdayaan Kader Posyandu adalah Sumber Daya (X2) dengan sig. $<0,05$ yakni 0,000 


\section{E. Pembahasan}

\section{Faktor Pemberdayaan Kader Posyandu sebagai intrapreneur melalui inovasi Produk BIMA-X berbasis Creative Enterpreneur}

Banyak faktor yang berpengaruh terhadap keberhasilan Pemberdayaan Kader Posyandu. Menurut penelitian (Indriyatni, 2013) bahwa terdapat 3 faktor penting, yakni diantaranya adalah Modal Kerja, Kemampuan/ Skill Sumber Daya dan Lokasi usaha yang mempengaruhi keberhasilan usaha mikro dan kecil. Pada Penelitian tersebut disebutkan bahwa faktor kemampuan skill sumber daya adalah faktor yang paling berpengaruh terhadap keberhasilan usaha. Sejalan dengan penelitian diatas, penelitian (Fino Susanto, Mora Claramita, Sri Handayani, 2017) menyebutkan bahwa peran kader posyandu balita dalam pemberdayaan masyarakat dibentuk dari motivasi internal dan eksternal, hambatan, sumber daya, potensi dan pengalaman mengembangkan kemampuan. Kader posyandu berperan sebagai pemberdayaan masyarakat. Kader memiliki kemampuan untuk membuat masyarakat ikut terlibat dengan semangat sosial. Semangat sosial kader kesehatan mampu memainkan peran penting dalam pemberdayaan masyarakat.

Inovasi Produk BIMA-X memiliki keunggulan yakni menggunakan sumber daya pangan/potensi lokal sehingga bisa menjadi salah satu faktor keberhasilan pemberdayaan kader posyandu sebagai intrapreneur. Menurut penelitian (Parwez, 2017) kewirausahaan berbasis masyarakat atau komunitas dianggap sebagai instrumen penting untuk realisasi potensi di antara masyarakat marjinal dan miskin yang terisolasi dari ekonomi arus utama dan penting dalam membawa peningkatan sosial. Nilai-nilai budaya, sumber daya bersama, hubungan, dan kerja saling percaya untuk masyarakat, dipupuk melalui hubungan pribadi yang erat untuk berfungsinya kegiatan ekonomi. Kegiatan wirausaha yang menciptakan barang publik lokal untuk masyarakat memiliki keunggulan komparatif dibandingkan dengan kegiatan yang berorientasi pasar absolut. Dalam penelitian ini menggunakan inovasi produk berbahan : biskuit PMT dan ekstrak daun kelor sebagai bahan pangan potensi lokal.

Berdasarkan hasil penelitian diatas didapatkan kesimpulan bahwa kegiatan wirausaha kader posyandu dapat berhasil apabila ada 4 faktor yang mendukung yakni : Komunikasi (transmisi, kejelasan dan penguasaan tehnis), Sumber Daya (Penguasaan tehnis/Keterampilan, Bahan Baku, Skill, Manajerial, dan Kualitas Layanan), Modal dan Fasilitas, serta Jejaring dan mitra usaha. 


\section{Faktor Sumber Daya terhadap Keberhasilan Pemberdayaan Kader Posyandu sebagai intrapreneur melalui inovasi Produk BIMA-X}

Berdasarkan penelitian diatas, faktor sumber daya merupakan faktor yang paling berpengaruh pada keberhasilan permberdayaan kader posyandu sebagai intrapreneur melalui inovasi produk BIMA-X.Hasil penelitian ini sejalan dengan penelitian (Constantino, 2012) yakni tentang penguatan sistem pemberdayaan suatu komunitas dengan melibatkan sumber daya yang ada, dimana pada penelitian tersebut meninjau tiga sistem diBrazilian Amazonia dan di Namibian Caprivi conservancies.Penelitian tersebut menganalisis strategi yang diadopsi dan kondisi yang memfasilitasi pemberdayaan lokal, sebagai potensi dampak pada konservasi.Hal ini memberikan wawasan tentang potensi daerah untuk memperkuat hasil pemberdayaan di Amerika Latin dan Afrika. Pada penelitian tersebut menilai empat dimensi pemberdayaan pada skala individu dan masyarakat: psikologis, sosial, ekonomi, dan politik. Kondisi yang memfasilitasi pemberdayaan lokal mencakup nilai sumber daya alam, hak untuk berdagang dan mengelola sumber daya, organisasi politik masyarakat, dan kolaborasi oleh para pemangku kepentingan.Berbagai strategi untuk memberdayakan masyarakat lokal termasuk mengintensifkan partisipasi lokal, menghubungkan mereka ke pendidikan lokal, memberi makan informasi kembali kepada masyarakat, dengan sengaja memilih peserta, membayar secara swadaya untuk layanan Monitoring, pemasaran memantau sumber daya, dan memasukkan masyarakat lokal ke dalam organisasi yang lebih luas.Meskipun masyarakat secara sosial dan politik diberdayakan, sistem monitoring lebih sering dipromosikan pemberdayaan individu.

Pada Faktor Sumber Daya, Kader Posyandu sebagai intrapreneur diharapkan dapat menjadi trainer atau faslitatorbagi masyarakat sehingga dapat mewujudkan masyarakat yang berdaya, kreatif serta sejahtera secara ekonomi dan kesehatan dengan memanfaatkan sumber daya dari potensi lokal daerah tersebut. Kader posyandu sebagai fasilitator mempunyai tugas untuk melakukan penyuluhan, pendampingan / penguasaan tehnis, kemahiran/skill, kualitas layanan maupun monitoring dan evaluasi kegiatan pemberdayaan masyarakat tersebut.

\section{F. Simpulan dan Saran}

\section{Simpulan}

Dari hasil uraian diatas, dapat disimpulkan sebagai berikut:

a. Pemberdayaan Kader Posyandu sebagaiintrapreneur berbasis creative enterpreneur dapat berhasil apabila ada 4 faktor yang 
mendukung yakni: Komunikasi (transmisi, kejelasan dan penguasaan tehnis), Sumber Daya (Penguasaan tehnis/Keterampilan, Bahan Baku, Skill, Manajerial, dan Kualitas Layanan), Modal dan Fasilitas, serta Jejaring dan mitra usaha.

b. Faktor Sumber daya merupakan faktor yang paling berpengaruh dalam Pemberdayaan Kader Posyandu sebagaiintrapreneur berbasis creative enterpreneur.

c. Kader Posyandu sebagai intrapreneur bertugas sebagai trainer yang memfasilitasi kegiatan pemberdayaan masyarakat melalui inovasi produk BIMA-X berbasis creative enterpreneur.

d. Kader posyandu sebagai fasilitator mempunyai tugas untuk melakukan penyuluhan, pendampingan / penguasaan tehnis, kemahiran/skill, kualitas layanan maupun monitoring dan evaluasi kegiatan pemberdayaan masyarakat tersebut.

\section{Saran}

Saran yang dapat dilaksanakan sesuai dari hasil penelitian sebagai berikut:

a. Adaya kerjasama mitra baik itu dari pemerintah maupun swasta dirasa sangat perlu untuk meningkatkan efektifitas pemberdayaan kaderposyandu dan masyarakat

b. Program pemberdayaan kader posyandu dan masyarakat diharapkan tida hanya dilakukan di kelurahan Randuagung tapi juga dilakukan di daerah lainnya, terutama daerah dengan status ekonomi dan status gizi nya masih rendah sehingga dapat bersinergi dengan program pemerintah daerah Gresik

c. Pada peneliti lain, diharapkan dapat meneliti faktor faktor lain yang menjadi faktor keberhasilan pemberdayaan kader posyandu atau masyarakat sebagai intrapreuner melalui inovasi produk pangan kreatif lainnya.

\section{G. Daftar Pustaka}

Ahap, P. (2015, Juni 25). Posyandu sebagai Alternatif Pemberdayaan Masyarakat . Retrieved from Kompasiana https://www.kompasiana.com/peterahab/550d4ad1a33311e11a2e3a3e/p osyandu-sebagai-alternatif-pemberdayaan-masyarakat

Ariestiningsih, E. S. (2018). Peran Unit Kegiatan Kemahasiswaan (UKM) Dalam Percepatan Masa Tunggu Lulusan (Suatu Studi Kasus Pada AKBID Delima Persada Gresik). FIRM Journal Of Management Studies , 32-47.

Avasilcai, A. B. (2016). Creative Enptrepreneur : Analytical Framework. Management International Symposium (pp. 21-28). Rumania: Procedia : 
Social and Behavioral Sciences. entrepeneurs anf innivator. Busiiness and Management , 1-57.

BKP, B. K. (2020, January 11). Pengembangan Usaha Pengolahan Pangan Lokal UMKM dan Rumah Tangga. Retrieved from http://bkp.pertanian.go.id: http://bkp.pertanian.go.id/pengembanganusaha-pengolahan-pangan-lokal-umkm-dan-rumah-tangga

Brian Barnard, D. H. (2018). Entrepreneurship, innovation and creativity: the creative process of entrepeneurs anf innivator. Busiiness and Management, 1-57.

Constantino, P. d. (2012). Empowering Local People through Community-based Resource Monitoring: a Comparison of Brazil and Namibia. Ecology and Society Journal, 22.

Departemen IImu Keluarga dan Konsumen, D. (2013, Desember 27). Fema IPB. Retrieved from http://ikk.fema.ipb.ac.id: http://ikk.fema.ipb.ac.id/v2/images/materi/kkbm2013konsumen.pdf

Dwi Faqihatus Syarifah, Eka Srirahayu Ariestiningsih. (2020). Pemanfaatan "Bi Saylor" Sebagai Produk Pangan Alternatif untuk pembangunan Gizi Berkelanjutan. Jurnal Karya Inovasi (KARINOV) Universitas Negeri Malang, 44-48.

Fino Susanto, Mora Claramita, Sri Handayani. (2017). Peran kader posyandu dalam pemberdayaanmasyarakat Bintan . Berita Kedokteran Masyarakat Vol 33 No 1, 13-18.

Hayati, N. (2014). Skripsi Latar Belakang tidak meningkatnya berat badan balita setelah mendapat pemberian makanan tambahan pemulihan (PMT) di Wilayah Kerja Puskesmas Pamulang. Jakarta: UIN Syarif Hidayatullah.

Indriyatni, L. (2013). ANALISIS FAKTOR FAKTOR YANG BERPENGARUH TERHADAP EBERHASILAN USAHA MIKRO DAN KECIL. Jurnal STIE Semarang Vol 5 No 1, 54-70.

Kementerian Kesehatan RI bekerjasama dengan Pokjanal Posyandu Pusat, K. (2012). Pelatihan Fasilitator Pemberdayaan Kader Posyandu. Jakarta: KEmenterian Kesehatan RI.

Laverack, L. a. (2008). Health Promotion in action : from local to global empowerment. London: WHO.

Nina Salamah, dkk. (2018, Agustus). Pelatihan Peran Serta Kader Posyandu dalam Pemberian Edukasi kepada Masyarakat. Jurnal Pemberdayaan: Publikasi Hasil Pengabdian kepada Masyarakat, 2(2), 249-256. 
Retrieved from http://journal2.uad.ac.id/index.php/jpmuad/article/view/393/pdf

Parwez, S. (2017). Community-based entrepreneurship:evidences from a retail case study. Journal of Innovation and Entrepreneurship, 6-14.

Permenkes. (2013). PEDOMAN PELAKSANAAN DAN PEMBINAAN PEMBERDAYAAN MASYARAKAT BIDANG KESEHATAN. Jakarta: Kementerian Kesehatan Republik Indonesia.

Rifqi, M. A. (3 March 2019). Pie Formula Biscuit Flour and Soy Protein Isolate as Alternative of High Protein Snack for Toddler. Indian Journal of Publiv Health Research\& Development Volume 10, Vol 10.

Saiman, L. (2015). Kewirausahaan Teori, Praktik, dan Kasus-kasus. Jakarta: Salemba Empat.

Suryana. (2014). Kewirausahaan Kiat dan Proses Menuju Sukses. Jakarta: Salemba Empat.

WHO. (2018, March 25). Tract 1 : Community empowerment. Community empowerment. 7th global conference on health promotion: track themes. World Health Organization., p. track1.

Winarno, F. (2018). Tanaman Kelor (Moringa oleifera): Nilai Gizi, Manfaat, dan Potensi Usaha. Jakarta: Gramedia Pustaka Utama. 